\title{
Two Different Compounds Formed from Copper(II) tetrafluoridoborate and $[1,2,4]$ triazolo[ $[1,5$-a]pyrimidine. Synthesis, Spectroscopy and Single-Crystal Structures
}

\author{
Eelke D. van den Bos • Ilpo Mutikainen • \\ Urho Turpeinen • Gerard A. van Albada • \\ Jaap G. Haasnoot • Jan Reedijk
}

Received: 10 December 2009/ Accepted: 16 January 2010/Published online: 12 February 2010

(C) The Author(s) 2010. This article is published with open access at Springerlink.com

\begin{abstract}
Two coordination compounds copper(II) with tetrafluoridoborate as the anion and [1,2,4]triazolo[1,5-a] pyrimidine (abbreviated as tp) as the ligand are presented, together with their crystal structure and spectroscopic properties. A light blue compound $\left[\mathrm{Cu}(\mathrm{tp})_{4}\left(\mathrm{H}_{2} \mathrm{O}\right)_{2}\right]\left(\mathrm{BF}_{4}\right)_{2}$ $\left(\mathrm{CH}_{3} \mathrm{OH}\right)(\mathbf{1})$ with a tetragonal chromophore and a dark blue compound $\left[\mathrm{Cu}(\mathrm{tp})_{5}\right]\left(\mathrm{BF}_{4}\right)_{2}\left(\mathrm{CH}_{3} \mathrm{OH}\right)(2)$ are formed from the same batch. Compound (2) has a quite unusual geometry for $\mathrm{Cu}$ (II) with just 5 tp ligands, homoleptically coordinated to the metal ion. Both compounds show interesting hydrogenbond interactions in the solid state, where coordinated water is intramolecularly bound to non-coordinated $\mathrm{N}$ atoms of tp (in 1), and methanol is attached to the anion (in 2).
\end{abstract}

Keywords Copper - Crystal structure .

Triazolopyrimidine

\section{Introduction}

Triazolopyrimidines (IUPAC recommended name: [1,2,4] triazolo[1,5-a]pyrimidines) are versatile ligands, as they have several nitrogen atoms with accessible lone pairs to bind to Lewis acids like metal ions.

E. D. van den Bos · G. A. van Albada .

J. G. Haasnoot · J. Reedijk ( $)$

Leiden Institute of Chemistry, Leiden University,

P.O. Box 9502, 2300 RA Leiden, The Netherlands

e-mail: reedijk@chem.leidenuniv.nl

I. Mutikainen - U. Turpeinen

Laboratory of Inorganic Chemistry, Department of Chemistry,

University of Helsinki, (A.I. Virtasen aukio 1),

P.O. Box 55, 00014 Helsinki, Finland
These ligands have a fused 5-membered and 6-membered ring system and as such resemble the nucleobases adenine and guanine of DNA (Scheme 1). A variety of coordination compounds of metals salts with the parent ligand and other triazoles is already known and reviewed $[1,2]$. Previous work from this laboratory has mainly been focusing on methyl substituted tp-based ligands [2-11]. Also other research groups have been studying this type of ligands [12-17]. Triazoles and pyrimidines may in some cases act as bridging ligands between metals, but they may also coordinate monodentately [18-20].

In a more recent papers we reported on transition-metal compounds with the ligands (5,7-diethyl[1,2,4]triazolo[1,5-a] pyrimidine), (5-methyl,7-phenyl[1,2,4]triazolo[1,5-a]pyrimidine) and (5,6,7-trimethyl[1,2,4]triazolo[1,5-a]pyrimidine) [21]; [22] and (7-isobutyl-5-methyl-[1,2,4]triazolo[1,5-a] pyrimidine) [23]. In the present study we report the X-ray crystal structures of two different copper $\mathrm{BF}_{4}$ compounds with the ligand $[1,2,4]$ triazolo[1,5-a]pyrimidine) (abbreviated as tp), i.e. $\left[\mathrm{Cu}(\mathrm{tp})_{4}\left(\mathrm{H}_{2} \mathrm{O}\right)_{2}\right]\left(\mathrm{BF}_{4}\right)_{2}\left(\mathrm{CH}_{3} \mathrm{OH}\right)$ (1) and $\left[\mathrm{Cu}(\mathrm{tp})_{5}\right]$ $\left(\mathrm{BF}_{4}\right)_{2}\left(\mathrm{CH}_{3} \mathrm{OH}\right)(2)$. Surprisingly with $\mathrm{Cu}(\mathrm{II})$ as the metal and tp as the only ligand, just a few X-ray crystal structures have been reported in the literature, i.e. with the anions $\mathrm{NCS}^{-}$and $\mathrm{Cl}^{-}$[24], $\mathrm{Br}^{-}$[10] and $\mathrm{ClO}_{4}^{-}$[25].

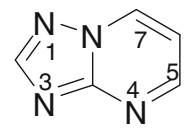

tp<smiles>Nc1ncnc2[nH]cnc12</smiles>

A<smiles>Nc1nc2[nH]cnc2c(=O)[nH]1</smiles>

G
Scheme 1 The ligand [1,2,4]triazolo[1,5-a]pyrimidine (tp) and its IUPAC recommended ring-atom numbering system, together with adenine $(\mathrm{A})$ and guanosine $(\mathrm{G})$ 


\section{Experimental Part}

\section{Starting Materials}

Hydrated metal salts, solvents, 1,3-propane-dione and 5-amino-1,2,4-triazole were used as commercially available, without further purification.

Synthesis of the Ligand

The synthesis of the ligand tp was carried out by a known condensation procedure $[2,26]$ at $160{ }^{\circ} \mathrm{C}$, from 1,3-propane-dione and 3-amino-1,2,4-triazole. Yield was found to be about $55 \%$. Characterisation of the free tp ligand was performed by elemental analysis, IR and NMR spectroscopy.

Synthesis of the Coordination Compounds

Synthesis of (1): A solution of $2 \mathrm{mmol}$ of $\mathrm{Cu}\left(\mathrm{BF}_{4}\right)_{2} \cdot 6 \mathrm{H}_{2} \mathrm{O}$ in $20 \mathrm{~mL}$ water was added to a warm aqueous solution of $2 \mathrm{mmol}$ of tp. Upon standing at room temperature blue crystals appeared after one or 2 weeks, which were collected by filtration. Yields were found to be about $40 \%$. By inspection under the microscope two different blue coloured (blue or light blue and other more dark blue) crystals were observed in the solution, which taken out of the solution very quickly disintegrated (by loss of lattice methanol), so that the difference of the two types could not be distinguished any more by eye. The two different types could not be synthesized separately, despite several attempts by changing the solvent, the metal-ligand ratio and the temperature.

\section{Physical and Analytical Methods}

Infrared spectra of the compounds were recorded on a PerkinElmer Paragon 1,000 FTIR spectrophotometer equipped with a Golden Gate ATR device, using the reflectance technique $\left(4,000-300 \mathrm{~cm}^{-1}\right.$, res. $\left.4 \mathrm{~cm}^{-1}\right)$.

\section{X-ray Diffraction Studies}

For each coordination compound a suitable crystal was selected from the mother liquid and quickly mounted to a glass fibre using the oil-drop method [27]. Diffraction data were collected on a Nonius KappaCCD diffractometer (graphite-monochromated MoK $\alpha$ radiation). The structures were solved by direct methods. The programs COLLECT [28], SHELXS-97 [29] SHELXL-97 [29] were used for data reduction, structure solution and structure refinement, respectively. Refinement of $F^{2}$ was performed against all reflections. All non-hydrogen atoms were refined anisotropically. Details for compound 1: The tetrafluoridoborate anion was found to be disordered and was refined in two positions with an SOF of 0.5. The oxygen atom of the methanol was also found disordered and given an SOF of 0.5. The carbon atom of the methanol molecule was refined in two positions each with an SOF of $<0.5$. The hydrogen atoms of the coordinated water molecule were taken from a Fourier-map. The hydrogen atoms of the methanol molecule were not located nor fixed. All other $\mathrm{H}$ atoms were introduced in calculated positions and refined with fixed geometry with respect to their carrier atoms.

Crystallographic data for both compounds are summarized in Table 1.

Table 1 Crystallographic data for compounds $\mathbf{1}$ and $\mathbf{2}$

\begin{tabular}{|c|c|c|}
\hline Compound & (1) & (2) \\
\hline Formula & $\mathrm{C}_{21} \mathrm{H}_{24} \mathrm{~B}_{2} \mathrm{CuF}_{8} \mathrm{~N}_{16} \mathrm{O}_{3}$ & $\mathrm{C}_{26} \mathrm{H}_{24} \mathrm{~B}_{2} \mathrm{CuF}_{8} \mathrm{~N}_{20} \mathrm{O}$ \\
\hline Molecular weight & 785.72 & 869.81 \\
\hline Crystal system & Monoclinic & Triclinic \\
\hline Space group & $\mathrm{C} 2 / \mathrm{m}$ & $\mathrm{P}-1$ \\
\hline$a,(\AA)$ & $19.498(2)$ & $10.2984(5)$ \\
\hline$b,(\AA)$ & $13.305(2)$ & $11.777(1)$ \\
\hline$c,(\AA)$ & $7.217(1)$ & $15.522(2)$ \\
\hline$\alpha,\left(^{\circ}\right)$ & 90 & $72.804(8)$ \\
\hline$\beta,\left(^{\circ}\right)$ & $110.84(1)$ & $82.058(8)$ \\
\hline$\gamma,\left({ }^{\circ}\right)$ & 90 & $73.711(6)$ \\
\hline$V,\left(\AA^{3}\right)$ & $1749.8(4)$ & 1723.1(3) \\
\hline$Z$ & 2 & 2 \\
\hline$D_{\text {calc }},\left(\mathrm{g} \mathrm{cm}^{-3}\right)$ & 1.491 & 1.676 \\
\hline$F(000)$ & 794 & 878 \\
\hline$\mu\left(\mathrm{cm}^{-1}\right)$ & 0.717 & 0.736 \\
\hline Crystal size (mm) & $0.40 \times 0.40 \times 0.40$ & $0.40 \times 0.20 \times 0.20$ \\
\hline Colour, shape & Light blue, block & Dark blue, block \\
\hline$\theta \min , \theta \max ^{\circ}$ & $3.21 ; 27.52$ & $2.88 ; 25.50$ \\
\hline Total reflections & 15291 & 26292 \\
\hline Total unique refl. & $2090\left(\mathrm{R}_{\mathrm{int}}=0.0280\right)$ & $\begin{array}{l}6287 \\
\quad\left(\mathrm{R}_{\mathrm{int}}=0.0266\right)\end{array}$ \\
\hline $\begin{array}{l}\text { No. of refined } \\
\text { parameters }\end{array}$ & 145 & 524 \\
\hline$R^{\mathrm{a}}, w R_{2}^{\mathrm{b}}$ & $0.0461,0.1308$ & $0.0416,0.1086$ \\
\hline$S^{\mathrm{C}}$ & 1.231 & 1.067 \\
\hline $\begin{array}{l}\text { Min. and max. } \\
\text { resd.dens.,e/ } \AA^{3}\end{array}$ & $1.086 ;-0.450$ & $1.144 ;-0.878$ \\
\hline
\end{tabular}




\section{Results and Discussion}

Description of the X-ray Structures Crystal Structure of $\left[\mathrm{Cu}(\mathrm{tp})_{4}\left(\mathrm{H}_{2} \mathrm{O}\right)_{2}\right]\left(\mathrm{BF}_{4}\right)_{2}\left(\mathrm{CH}_{3} \mathrm{OH}\right)$ (1)

An ORTEP perspective view of $\mathbf{1}$ is presented in Fig. 1. Selected bond lengths and angles are given in Table 2. The unit cell consists of a $\left[\mathrm{Cu}(\mathrm{tp})_{4}\left(\mathrm{H}_{2} \mathrm{O}\right)_{2}\right]^{2+}$ moiety, two uncoordinating (disordered) tetrafluoridoborate anions and a (disordered) lattice methanol molecule. A centre of symmetry is located at $\mathrm{Cu}$, and a mirror plane is running through the $\mathrm{O}-\mathrm{Cu}-\mathrm{O}$ axis, bisecting the $\mathrm{N}-\mathrm{Cu}-\mathrm{N}$ angle. The $\mathrm{Cu}$ (II) ion has a distorted octahedral environment, of which the basal plane is formed by four nitrogen atoms of four tp ligands with $\mathrm{Cu}-\mathrm{N}$ distance $2.017(2) \AA$. The apical positions are formed by an oxygen atom of the water molecules with a $\mathrm{Cu}-\mathrm{O}$ distance 2.472(3) $\AA$. All angles are $180^{\circ}$, due to the symmetry. The lattice structure is stabilised by bifurcated hydrogen bonding of the water hydrogen atoms to the $\mathrm{N} 4$ of each tp ligand $(\mathrm{O} \cdots \mathrm{N}$ distance $2.870(3) \AA$ ) and to the fluorine atoms of the $\mathrm{BF}_{4}$ anion (O..F distance 3.033(5) $\AA$ ). (see Fig. 2) No other hydrogen

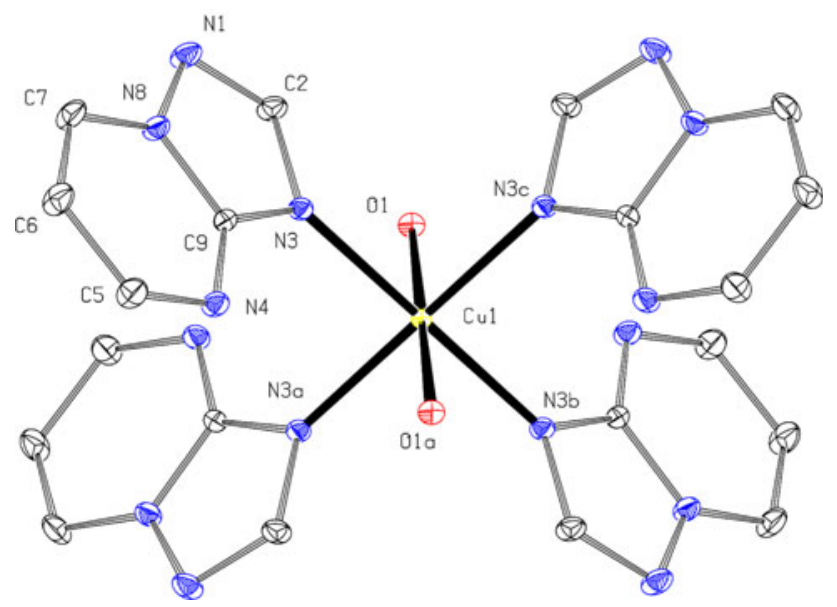

Fig. 1 ORTEP drawing (30\% probability level) of $\mathrm{Cu}(\mathrm{tp})_{4}$ $\left.\left(\mathrm{H}_{2} \mathrm{O}\right)_{2}\right]\left(\mathrm{BF}_{4}\right)_{2}\left(\mathrm{CH}_{3} \mathrm{OH}\right)(\mathbf{1})$. The uncoordinating tetrafluoridoborate and methanol molecules, as well as the hydrogen atoms, are omitted for clarity

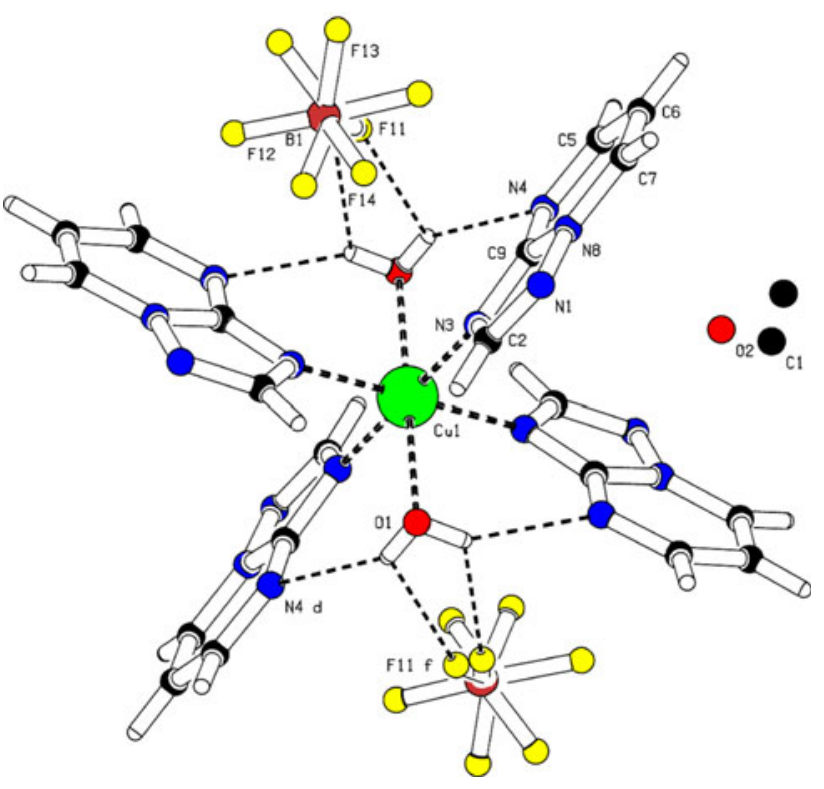

Fig. 2 H-bond system of (1)

bonds could be observed due to the severe disorder of the methanol molecule. Details are given in Table 2.

Crystal Structure of $\left[\mathrm{Cu}(\mathrm{tp})_{5}\right]\left(\mathrm{BF}_{4}\right)_{2}\left(\mathrm{CH}_{3} \mathrm{OH}\right)(2)$

An ORTEP perspective view of $\mathbf{2}$ is shown in Fig. 2. Selected bond lengths and angles are given in Table 3. The unit cell contains the square pyramidal $\left[\mathrm{Cu}(\mathrm{tp})_{5}\right]^{2+}$ moiety, two non-coordinating tetrafluoridoborate anions and one uncoordinating methanol molecule. The $\mathrm{Cu}$ (II) ion has a square pyramidal geometry formed by four nitrogen atoms of four tp ligands ( $\mathrm{Cu}-\mathrm{N}$ distances from 2.009(2) to 2.028(2) $\AA$ ) and one nitrogen atom of a fifth tp ligand $(\mathrm{Cu}-\mathrm{N}$ distance $2.256(2) \AA)$. The largest $\mathrm{N}-\mathrm{Cu}-\mathrm{N}$ angles are $162.58(10)$, 168.54(10) ${ }^{\circ}$ (Fig. 3).

The geometry of 5-coordinated compounds can be expressed by the he structural parameter $\tau$ (the structural parameter $\tau$ describes the relative amount of trigonality; $\tau=0$ for square pyramid and $\tau=1$ for trigonal bipyramidal) [30]. In this case $\tau=0.10$, so the geometry can be described as distorted square pyramidal.

Table 2 Selected bond lengths $(\AA)$ and angles $\left({ }^{\circ}\right)$ of $(\mathbf{1})$

\begin{tabular}{|c|c|c|c|c|c|}
\hline $\mathrm{Cu} 1-\mathrm{O} 1$ & $2.472(3)$ & $\mathrm{Cu} 1-\mathrm{N} 3$ & $2.017(2)$ & & \\
\hline $\mathrm{O} 1-\mathrm{Cu} 1-\mathrm{N} 3$ & $86.20(8)$ & $\mathrm{O} 1-\mathrm{Cu} 1-\mathrm{O} 1 \mathrm{a}$ & 180.0 & & \\
\hline $\mathrm{O} 1-\mathrm{Cu} 1-\mathrm{N} 3 \mathrm{a}$ & $93.80(8)$ & $\mathrm{N} 3-\mathrm{Cu} 1-\mathrm{N} 3 \mathrm{a}$ & $88.67(10)$ & & \\
\hline $\mathrm{N} 3-\mathrm{Cu} 1-\mathrm{N} 3 \mathrm{~b}$ & 180.00 & $\mathrm{~N} 3-\mathrm{Cu} 1-\mathrm{N} 3 \mathrm{c}$ & $91.33(10)$ & & \\
\hline $\mathrm{O} 1 \mathrm{a}-\mathrm{Cu} 1-\mathrm{N} 3 \mathrm{a}$ & $86.20(8)$ & & & & \\
\hline \multicolumn{2}{|c|}{ Hydrogen bonds: (bifurcated $\mathrm{H}$ bond) } & $\mathrm{D}-\mathrm{H}$ & $\mathrm{H} \cdots \mathrm{A}$ & $\mathrm{D} \cdots \mathrm{A}$ & $\mathrm{D}-\mathrm{H} \cdots \mathrm{A}$ \\
\hline \multicolumn{2}{|c|}{$\mathrm{O}(1)-\mathrm{H}(1) \cdots \mathrm{F}(11)[-\mathrm{x},-\mathrm{y},-\mathrm{z}]$} & $0.78(4)$ & $2.55(4)$ & $3.033(5)$ & $122(4)$ \\
\hline \multicolumn{2}{|c|}{$\mathrm{O}(1)-\mathrm{H}(1) \cdots \mathrm{N}(4)[-\mathrm{x},-\mathrm{y},-\mathrm{z}]$} & $0.78(4)$ & $2.17(4)$ & $2.870(3)$ & $150(4)$ \\
\hline
\end{tabular}


Table 3 Selected bond lengths $(\AA)$ and angles $\left({ }^{\circ}\right)$ of $(\mathbf{2})$

\begin{tabular}{llll}
\hline Cu1-N13 & $2.028(2)$ & $\mathrm{Cu} 1-\mathrm{N} 23$ & $2.012(2)$ \\
$\mathrm{Cu} 1-\mathrm{N} 33$ & $2.256(2)$ & $\mathrm{Cu} 1-\mathrm{N} 43$ & $2.015(2)$ \\
$\mathrm{Cu} 1-\mathrm{N} 53$ & $2.009(2)$ & & $93.87(9)$ \\
$\mathrm{N} 13-\mathrm{Cu} 1-\mathrm{N} 23$ & $92.14(10)$ & $\mathrm{N} 13-\mathrm{Cu} 1-\mathrm{N} 33$ & $90.10(9)$ \\
$\mathrm{N} 13-\mathrm{Cu} 1-\mathrm{N} 43$ & $162.58(10)$ & $\mathrm{N} 13-\mathrm{Cu} 1-\mathrm{N} 53$ & $87.60(9)$ \\
$\mathrm{N} 23-\mathrm{Cu} 1-\mathrm{N} 33$ & $98.80(9)$ & $\mathrm{N} 23-\mathrm{Cu} 1-\mathrm{N} 43$ & $103.39(9)$ \\
$\mathrm{N} 23-\mathrm{Cu} 1-\mathrm{N} 53$ & $168.54(10)$ & $\mathrm{N} 33-\mathrm{Cu} 1-\mathrm{N} 43$ & $86.92(9)$ \\
$\mathrm{N} 33-\mathrm{Cu} 1-\mathrm{N} 53$ & $92.27(9)$ & $\mathrm{N} 43-\mathrm{Cu} 1-\mathrm{N} 53$ & $\mathrm{D} \cdots \mathrm{A}$ \\
$\mathrm{Hydrogen} \mathrm{bonds}$ & $\mathrm{D}-\mathrm{H}$ & $\mathrm{H} \cdots \mathrm{A}$ & $2.833(6)$ \\
$\mathrm{O}(1)-\mathrm{H}(1) \cdots \mathrm{F}(14)[1-\mathrm{x},-1-\mathrm{y},-\mathrm{z}]$ & 0.84 & 2.04 & $\mathrm{D}-\mathrm{H} \cdots \mathrm{A}\left({ }^{\circ}\right)$ \\
\hline
\end{tabular}

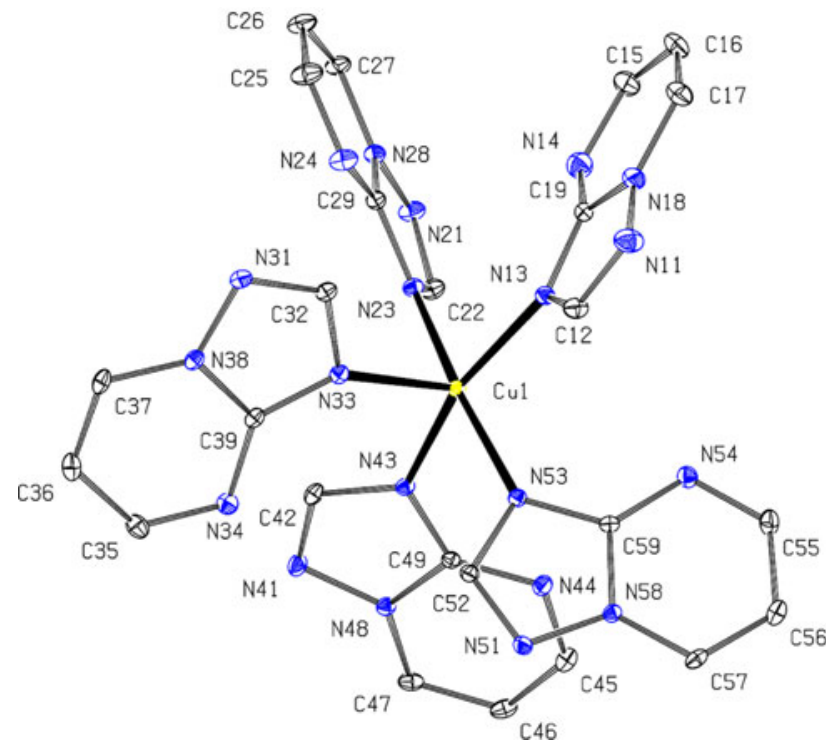

Fig. 3 ORTEP drawing (30\% probability level) of $\left[\mathrm{Cu}(\mathrm{tp})_{5}\right]\left(\mathrm{BF}_{4}\right)_{2}$ $\left(\mathrm{CH}_{3} \mathrm{OH}\right)$ (2). The uncoordinating tetrafluoridoborate and methanol molecules, as well as the hydrogen atoms, are omitted for clarity

The lattice structure is stabilised by hydrogen bonding of the oxygen atom of the methanol molecule to the $\mathrm{BF}_{4}$

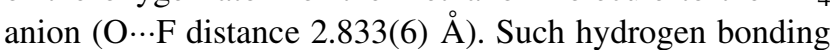
with $\mathrm{BF}_{4}$ is relatively rare, but easily detectable with IR for $\mathrm{X}-\mathrm{H}$ groups binding to it [31]. Geometric details are given in Table 3 (Fig. 4).

\section{IR Spectroscopy}

Due to the fact that the two different compounds were very virtually impossible to be separated manually (see experimental part), only an overall IR spectrum could be recorded for characterisation (see Fig. S1). The characteristic ligand vibrations differ only slightly from the free ligand, as would be expected. The $\mathrm{BF}_{4}$ anion vibrations are observed at $1051-1039 \mathrm{~cm}^{-1}$ as a split band. At around $3348 \mathrm{~cm}^{-1}$ a broad absorption is observed, which is

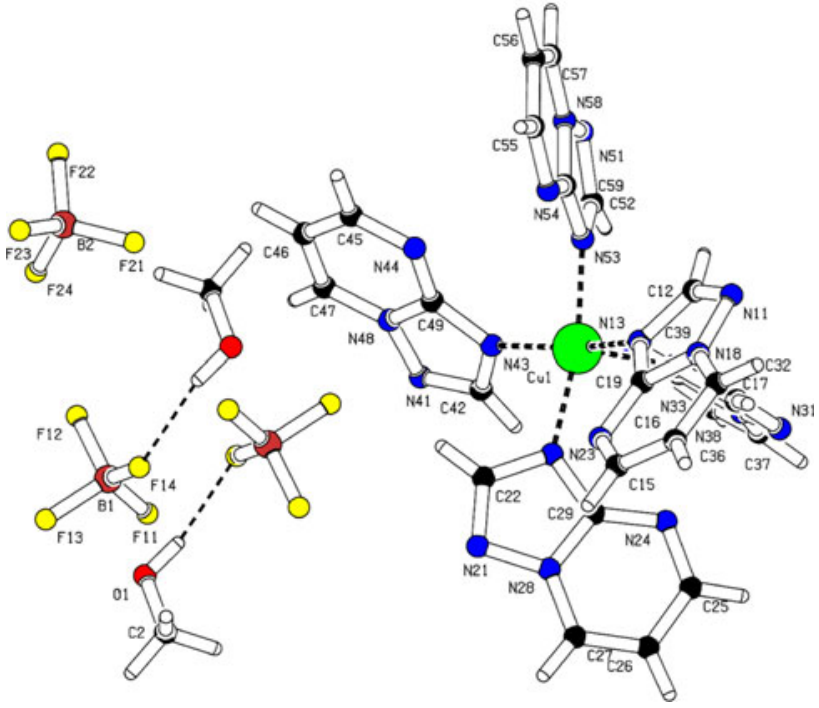

Fig. 4 H-bond system in the lattice of (2)

ascribed to the $v_{\mathrm{OH}}$ of the water and methanol molecules, hydrogen bonded to the $\mathrm{BF}_{4}$ anions.

\section{Concluding Remarks}

The study described above has resulted in two new $\mathrm{Cu}$ (II) tetrafluoridoborate compounds with unsubstituted tp as a ligand. The two forms crystallise from the same batch, and despite several attempts, no conditions were found to obtain either one or the other compound in pure form. These two compounds appear to be the first compounds of $\mathrm{Cu}(\mathrm{II})$ and $\mathrm{BF}_{4}{ }^{-}$with tp as the ligand, which have been characterized by X-ray structures. Even with substituted tp ligands only one case is known [22].

Compound 2 has an unusual geometry with 5 tp ligands coordinated in an homoleptic manner, generating a fivecoordinate geometry. Five-coordinated $\mathrm{Cu}$ (II) compounds are quite common, but with only a single type of a bulky ligand, they are rarely observed. 


\section{Supplementary Data}

CIF files of both structures, and IR spectra of tp and the complexes are given as supplementary material. The files CCDC-756398 and 756399 also contain the crystallographic data for $\mathbf{1}$ and $\mathbf{2}$. These data can be obtained free of charge via http://www.ccdc.cam.ac.uk/conts/retrieving. html, or from the Cambridge Crystallographic Data Centre, 12 Union Road, Cambridge CB2 1EZ, UK; fax: (+44) 1223-336-033; or e-mail: deposit@ccdc.cam.ac.uk. A checkcif file for both compounds is also available.

Acknowledgments This work was performed in the framework of the freshmen students research project "Leren Onderzoeken 1" (Learning Research 1) in the BSc programme "Molecular Science and Technology", a recently started concept in the joint programme of Delft University of Technology and Leiden University.

Open Access This article is distributed under the terms of the Creative Commons Attribution Noncommercial License which permits any noncommercial use, distribution, and reproduction in any medium, provided the original author(s) and source are credited.

\section{References}

1. Salas JM, Romero MA, Sanchez MP, Quiros M (1999) Coord Chem Rev 195:1119

2. Haasnoot JG (2000) Coord Chem Rev 200:131

3. Biagini-Cingi M, Manotti-Lanfredi AM, Tiripicchio A, Cornelissen JP, Haasnoot JG, Reedijk J (1987) Inorg Chim Acta 127:189

4. Biagini Cingi M, Manotti Lanfredi AM, Tiripicchio A, Haasnoot JG, Reedijk J (1986) Acta Cryst C C42:1509

5. Biagini Cingi M, Manotti Lanfredi AM, Tiripicchio A, Haasnoot JG, Reedijk J (1984) Inorg Chim Acta 86:137

6. Dirks EJ, Haasnoot JG, Kinneging AJ, Reedijk J (1987) Inorg Chem 26:1902

7. Lenstra ATH, Slot HJB, Beurskens PT, Haasnoot JG, Reedijk J (1989) Recl Trav Chim Pays-Bas 108:133

8. Sanni SB, Behm H, Beurskens PT, Cornelissen JP, Haasnoot JG, Lenstra ATH (1987) J CrystallSpectr Res 17:81
9. Szlyk E, Wojtczak A, Jaskolski M, Gilski M, Haasnoot JG, Reedijk J (1997) Inorg Chim Acta 260:145

10. van Albada GA, de Graaff RAG, Haasnoot JG, Schild J, Reedijk J (1991) Acta Crystallogr Sect C-Cryst Struct Commun 47:946

11. Velders AH, Bergamo A, Alessio E, Zangrando E, Haasnoot JG, Casarsa C, Cocchietto M, Zorzet S, Sava G (2004) J Med Chem 47:1110

12. Lakomska I, Szlyk E, Sitkowski J, Kozerski L, Wietrzyk J, Pelczynska M, Nasulewicz A, Opolski A (2004) J Inorg Biochem 98:167

13. Lakomska I, Wojtczak A, Sitkowski J, Kozerski L, Szlyk E (2007) Polyhedron 26:803

14. Romero MA, Salas JM, Quiros M, Williams DJ, Molina J (1993) Trans Met Chem 18:595

15. Salas JM, Enrique C, Romero MA, Takagi K, Aoki K, Miyashita Y, Suh IH (1992) Polyhedron 11:2903

16. Szlyk E, Lakomska I, Surdykowski A, Glowiak T, Pazderski L, Sitkowski J, Kozerski L (2002) Inorg Chim Acta 333:93

17. Szlyk E, Pazderski L, Lakomska I, Kozerski L, Sitkowski J (2002) Magn Reson Chem 40:529

18. Bencini A, Gatteschi D, Zanchini C, Haasnoot JG, Prins R, Reedijk J (1985) Inorg Chem 24:2812

19. Ferrer S, Haasnoot JG, Reedijk J, Muller E, Biagini-Cingi M, Lanfranchi M, Manotti-Lanfredi AM, Ribas J (2000) Inorg Chem 39:1859

20. Riggio I, van Albada GA, Mutikainen I, Turpeinen U, Reedijk J (2000) Acta Cryst 56:E380

21. Balkaran JM, van Bezouw SCP, van Bruchem J, Verasdonck J, Verkerk PC, Volbeda AG, Mutikainen I, Turpeinen U, van Albada GA, Gamez P et al (2009) Inorg Chim Acta 362:861

22. Adriaanse JH, Askes SHC, van Bree Y, van Oudheusden S, van den Bos ED, Günay E, Mutikainen I, Turpeinen U, van Albada GA, Haasnoot JG et al (2009) Polyhedron 28:3143

23. Günay E, Mutikainen I, Turpeinen U, van Albada GA, Haasnoot JG, Reedijk J: (2009) J Chem Cryst: submitted

24. Biagini-Cingi M, Manotti-Lanfredi AM, Tiripicchio A, Cornelissen JP, Haasnoot JG, Reedijk J (1987) Inorg Chim Acta 129:217

25. Maldonado CR, Quiros M, Salas JM (2008) Polyhedron 27:2779

26. Bülow C, Haas K (1909) Chem Ber 42:4638

27. Kottke T, Stalke D (1993) J Appl Crystallogr 26:615

28. Nonius X-ray Data COLLECTION. In: COLLECT Nonius BV, Delft, The Netherlands. 2002

29. Sheldrick GM (2008) Acta Cryst (A) 64:112

30. Addison AW, Rao TN, Reedijk J, van Rijn J, Verschoor GC (1984) J Chem Soc, Dalton Trans: 1349

31. Reedijk J (1971) Recl Trav Chim Pays-Bas 90:117 